\title{
Seasonal Variation of Atmospheric Composition of Water-Soluble Inorganic Species at Rural Background Site in Tanzania, East Africa \\ ${ }^{1}$ Mkoma S.L., ${ }^{2}$ Wang W. , ${ }^{2}$ Maenhaut W. and ${ }^{1}$ Tungaraza C.T.
}

\begin{abstract}
Samples of coarse, fine and PM10 aerosols were collected at a rural Morogoro sites, during the 2005 dry season and 2006 wet season campaigns using a "Gent" PM10 stacked filter unit sampler with sequential Nuclepore polycarbonate filters. A total of 80 aerosol samples were analyzed for water-soluble inorganic ions components using lon Chromatography. The mean concentration for the anions $\mathrm{Cl}, \mathrm{NO}_{3}^{-}$, and $\mathrm{SO}_{4}{ }^{2-}$ and the cations $\mathrm{Na}^{+}$, $\mathrm{NH}_{4}^{+}, \mathrm{K}^{+}, \mathrm{Mg}^{2+}, \mathrm{Ca}^{2+}$, showed seasonal variation in all size fractions with higher levels during the 2005 dry season campaign than the 2006 wet season campaign. The mean concentrations and associated standard deviation of fine, coarse and PM10 mass were, $17 \pm 4,52 \pm 27$ and $69 \pm 29 \mu \mathrm{g} / \mathrm{m}^{3}$ during the 2005 dry season campaign and $13 \pm 5,34 \pm 23$ and $47 \pm 25 \mu \mathrm{g} / \mathrm{m}^{3}$ for the 2006 wet season campaign, respectively. $\mathrm{Ca}^{2+}$ was the most important cation and the $\mathrm{SO}_{4}{ }^{2-}$ was the main acidifying anionic component in $\mathrm{PM} 10$ while $\mathrm{NH}_{4}^{+}$was the most abundant cation in the fine fraction and $\mathrm{Cl}$ the main anionic species in the coarse fraction. The ion balance ratios were all larger than 1.0; they range from 1.30 to 1.44 for the fine fraction and from 2.01 to 3.14 for the coarse fraction. The carbonates were not measured by lon Chromatography therefore; these missing carbonates are thought to be largely responsible for the observed deviation from 1.0. The study suggests that primary sources such as soil dust dispersion and biomass burning made a significant contribution to the atmospheric particulate pollution in Morogoro.
\end{abstract}

Keywords: Ion chromatography; Aerosol Characterization; coarse, fine and PM10 fractions; Meteorology

\section{Introduction}

$$
\text { There is an increasing awareness of }
$$
particulate matter (PM) on environmental systems and human health. Atmospheric particles may greatly vary in their size, chemical composition, and temporal and spatial variations. Among the suspended particles in ambient air, atmospheric particulate matter with an aerodynamic diameter less than $10 \mu \mathrm{m}$ (PM10), and especially the fine particle fraction with aerodynamic diameter less than $2.5 \mu \mathrm{m}$ (PM2.5) are of considerable concern. The chemical composition of PM10 and PM2.5 is critically important to gain insights into sources and their atmospheric formation pathways and of their toxicity and to evaluate the effectiveness of abatement strategies for relevant emission sectors (Harrison et al., 2004; Tippayawong, et al., 2006; Giri, et al., 2006).

The major inorganic ions components of PM2.5 are reported to be sulphate $\left(\mathrm{SO}_{4}{ }^{2-}\right)$, nitrate $\left(\mathrm{NO}_{3}{ }^{-}\right)$, ammonium $\left(\mathrm{NH}_{4}{ }^{+}\right)$(Turnbull and Harrison, 2000; Lee and Kang, 2001) and are associated with atmospheric visibility degradation, adverse human health effects, and acidity of precipitation (Dockery and Pope, 1996; Pope et al., 2002; Watson, 2002; Villeneuve et al., 2003; IPCC, 2007). Ion chromatography (IC) is widely used for the measurement of inorganic ions in particles since it offers advantages in terms of sensitivity and multiple analyte determination in a single assay (McMurry, 2000; Wilson et al., 2002).

So far, only a few aerosol measurements are available for Tanzania (Koleleni, 2002; Bennet et al., 2005; Msafiri, 2005) and particularly in Morogoro (Mkoma et al., 2009a,b). In this study, ion chromatography (IC) in conjunction with ultrasonic extraction was employed for the characterisation of water-soluble inorganic ions in PM10-2, PM2 (hereafter referred to as coarse and fine particles) and total PM10 aerosols at a rural site in Morogoro, Tanzania. The influences of meteorology on PM and ions levels are reported and in addition the ionic balance and the seasonal variations of the water-soluble ions in different size fractions have been discussed.

\section{Materials and Methods}

The sampling campaign at rural Morogoro took place between July 2005 and April 2006. The site is located at $6^{\circ} 49^{\prime} 39.7^{\prime \prime} \mathrm{S}$, $37^{\circ} 39^{\prime} 48.1^{\prime \prime} \mathrm{E}$, altitude $526 \mathrm{~m}$ a.s.l, and is at about $200 \mathrm{~km}$ to the west of the Indian Ocean. Aerosol samples were collected using a "Gent" PM10 stacked filter unit (SFU)

\footnotetext{
${ }^{1}$ Department of Physical Sciences, Faculty of Science, Sokoine University of Agriculture (SUA), P.O. Box 3038, Morogoro, Tanzania*stelyusm@gmail.com

2 Department of Analytical Chemistry, Institute for Nuclear Sciences, Ghent University, Proeftuinstraat 86, B-9000 Gent, Belgium
} 
sampler, PM10(NN), (Maenhaut et al., 1994; Hopke et al., 1997) with coarse (Apiezoncoated) and fine Nuclepore polycarbonate filters (pore sizes 8 and $0.4 \mu \mathrm{m}$, respectively). The sampler operated at a flow rate of 17 $\mathrm{L} / \mathrm{min}$. At this flow rate the coarse filter of the SFU sampler collects the particles with aerodynamic diameter (AD) between 2 and 10 $\mu \mathrm{m}$, while the fine filter collects the size fraction $<2 \mu \mathrm{m} \mathrm{AD}$. The samplers were placed on the roof of a building $6 \mathrm{~m}$ above ground level at the main campus of Sokoine University of Agriculture (SUA). A detailed description of the site is given elsewhere (Mkoma et al., 2009a). During the dry season campaign between July and August 2005, a total of 51 samplings and 7 field blanks (of 30 s) were performed. The first 5 samplings were of 24 hours and the subsequent 46 samplings were daytime and nighttime collections of 12 hours each. The 24-hour samplings started at 8.00 am local time (UTC +3 hours) and the 12-hour collections started at 6.30 am and 6.30 pm for daytime and nighttime respectively. The 2006 wet season campaign was carried out from March to April 2006, with 29 collections of 24 hours and 7 field blanks with each sampler. The exchange of filters during the 2006 wet season campaign was done at 8.00 am (Local time, UTC +3 hours). From each campaign, the exposed filters and field blanks were placed into polycarbonate Petrislide dishes and kept frozen at $-20{ }^{\circ} \mathrm{C}$ during storage and transported cool to the Institute for Nuclear Sciences, INW (Ghent, Belgium) for analysis.

The PM mass of the collected field blanks and actual samples were obtained by weighing the filters before and after sampling with a Mettler MT5 microbalance (sensitivity $1 \mu \mathrm{g}$ ). Before weighing, the filters were conditioned at relative humidity of $50 \%$ and a temperature of $20{ }^{\circ} \mathrm{C}$ for 24 hour and the weighings were done at these conditions. The uncertainty (1 standard deviation) of the PM mass determinations is estimated at $5 \mu \mathrm{g}$ for the Nuclepore polycarbonate filters (Hitzenberger et al., 2004). Furthermore, one half of each Nuclepore polycarbonate filter (coarse and fine) was placed in a $15 \mathrm{~mL}$ polystyrene tube and ultrasonically extracted with $10 \mathrm{~mL}$ of Millipore Simplicity water for 1 hour. The major water-soluble inorganic ions, namely $\mathrm{Na}^{+}, \mathrm{NH}_{4}^{+}, \mathrm{K}^{+}, \mathrm{Mg}^{2+}, \mathrm{Ca}^{2+}, \mathrm{SO}_{4}^{2-}, \mathrm{NO}_{3}{ }^{-}$ and $\mathrm{Cl}^{-}$in the extracts were then analysed by ion chromatography (IC), using a Dionex $4500 \mathrm{i}$ instrument as described in detail elsewhere (Maenhaut et al. 2002). All the reported water-soluble ion concentrations and PM mass have been corrected using field blanks and the data for the coarse (PM10-2) and fine (PM2) filters were added in order to obtain a total PM10 data.

\section{Results and discussions}

\section{i) PM mass concentration}

The mean mass concentrations and associated standard deviation for the fine, coarse, PM10 size fractions during the 2005 dry season campaign were $17 \pm 4,52 \pm 27,69 \pm 29$ $\mu \mathrm{g} / \mathrm{m}^{3}$ respectively. The corresponding values for the 2006 wet season campaign were $13 \pm 5$, $34 \pm 23$ and $47 \pm 25$ respectively. The average contributions of fine (PM2) particulate mass to the PM10 mass during the two campaigns were $49 \pm 9$ and $37 \pm 6 \%$ for the 2005 dry, and 2006 wet seasons, respectively, indicating that most of the PM10 mass was in the coarse size fraction. The time series of the PM mass in the fine, coarse and PM10 size fractions obtained at our sampling site in Morogoro during the two seasons campaigns are shown in Figures 1 and 2. The concentrations of the PM mass in all size fractions showed seasonal differences, with the 2005 dry season campaign having the highest concentrations. The variations in ambient PM10 levels observed during the campaigns resulted from variations in sources strengths and in meteorological conditions, such as mixing height and precipitation. As for day and night samples of the 2005 dry season campaign, the site showed day/night differences for the PM10-2 and PM10 mass levels which are expected to be attributed by primary sources such as soil dust dispersion and intense biomass burning during the day.

Since there are no standard limits for PM10 or PM2.5 levels in Tanzania, the data from this work are compared to EU standards. In the EU the daily limit concentration for PM10 mass is $50 \mu \mathrm{g} / \mathrm{m}^{3}$, which cannot be exceeded more than 35 times per year, and the yearly average concentration (based on daily measurements) is $40 \mu \mathrm{g} / \mathrm{m}^{3}$ (EU Directive, 1999). In Morogoro, the daily PM10 concentrations exceeded the daily EU standard 17 times during the 2005 dry season campaign and was within the limit in 2006 wet season campaign.

The levels of the PM10 mass at the rural background site of Morogoro are in line 
with the levels at rural sites in Europe, as reported in the European aerosol phenomenology study (Van Dingenen et al., 2004). Our data where also comparable to the few available other data sets for eastern and southern Africa. For the remote site of Rukomechi in northern Zimbabwe, median PM10 mass concentrations of $8 \mu \mathrm{g} / \mathrm{m}^{3}$ and 23 $\mu \mathrm{g} / \mathrm{m}^{3}$ were obtained for the wet and the dry seasons, respectively (Nyanganyura et al., 2007), which are lower than the data for Morogoro.

ii) Concentration of water-soluble ions

The chemical characteristics of the water-soluble inorganic ions in the coarse and fine size fractions collected during the 2005 dry season and 2006 wet season campaigns in Morogoro are shown in Table 1 (Note that the median data for the water-soluble ions during the 2005 dry season campaign have also reported in Mkoma et al., 2009b). In both size fractions, the mean concentration for the anions $\mathrm{Cl}^{-}, \mathrm{NO}_{3}{ }^{-}$, and $\mathrm{SO}_{4}{ }^{2-}$ and the cations $\mathrm{Na}^{+}, \mathrm{NH}_{4}^{+}, \mathrm{K}^{+}, \mathrm{Mg}^{2+}, \mathrm{Ca}^{2+}$, are highest in the 2005 dry season campaign and lowest in the 2006 wet season campaign. However, $\mathrm{Ca}^{2+}$ was the most important cation and the $\mathrm{SO}_{4}{ }^{2-}$ main anionic species in PM10 while $\mathrm{NH}_{4}{ }^{+}$was the most abundant cation in the fine size fraction and $\mathrm{Cl}^{-}$the main anionic species in the coarse fraction.

The median $\mathrm{SO}_{4}{ }^{2-}$ and $\mathrm{NO}_{3}{ }^{-}$ concentration in the 2005 dry season campaign was 4.5 and 8.5 times respectively higher than in the 2006 wet season campaigns. The difference between seasons is more pronounced for nitrate than for sulphate. The partition of $\mathrm{NO}_{3}{ }^{-}$between the gas phase and particulate phase depends strongly on temperature $(\mathrm{T})$, relative humidity $(\mathrm{RH})$, and ammonia concentration, and larger particulate nitrate concentrations are expected at low temperature and high $\mathrm{RH}$. There was no dramatic seasonal difference in $\mathrm{RH}$, whereas the temperature was lowest in the dry season. Thus, the larger nitrate levels in this season are expected. On the other hand, biomass burning is an important source of $\mathrm{NO}_{\mathrm{x}}$, the precursor gas of nitrate, and enhanced biomass burning in the dry season may be responsible for the elevated nitrate levels then. The median for particulate $\mathrm{NH}_{4}{ }^{+}$is also higher in the dry than in the wet season. This may be due to enhanced ammonia levels then. Unfortunately, no data for the gases $\mathrm{SO}_{2}, \mathrm{NO}_{\mathrm{x}}$, and $\mathrm{NH}_{3}$ are available for the 3 campaigns. The medians for $\mathrm{Ca}^{2+}, \mathrm{Na}^{+}, \mathrm{Mg}^{2+}, \mathrm{K}^{+}$, and $\mathrm{Cl}^{-}$are higher in the dry than in the wet season campaigns. The highest median for $\mathrm{K}^{+}$in the dry season campaign is expected, as $\mathrm{K}^{+}$is a good indicator for biomass burning, which is most enhanced in the dry season. When compared to literature data for rural sites in Europe, it appears that the levels in PM10 of $\mathrm{SO}_{4}{ }^{2-}, \mathrm{NO}_{3}{ }^{-}$, and $\mathrm{NH}_{4}{ }^{+}$ are substantially lower at Morogoro than at the European rural sites (Putaud et al., 2004; Ocskay et al., 2006).

iii) Fine to PM10 ratios

The average fine to PM10 concentration ratios were calculated for the PM mass, and various water-soluble inorganic ions; the results are shown in Figure 3. The average PM2/PM10 concentration ratios and associated standard deviations for the PM mass were $0.49 \pm 0.09$, and $0.37 \pm 0.06$ for the 2005 dry, and 2006 wet season campaigns, respectively. The higher PM2/PM10 ratio for the PM mass in the dry season may be due to a larger contribution from pyrogenic aerosol, which is known to be mostly associated with fine particles. Figure 3 further shows that ammonium and sulphate were mainly present in the fine size fraction. In contrast, nitrate was mainly associated with the coarse particles especially during the 2006 wet season campaigns which accounted for $65 \%$ of the PM10 $\mathrm{NO}_{3}{ }^{-}$. The sea-salt elements $(\mathrm{Na}, \mathrm{Mg}$, $\mathrm{Cl})$ were predominantly associated with the coarse size fraction. K (a well-known indicator for biomass burning) was mostly associated with the fine particles (in contrast to $\mathrm{Ca}$ ). This suggests that biomass burning was important in Morogoro, especially in the 2005 dry season campaign, when around $80 \%$ of the PM10 K was in the PM2 size fraction.

iv) Ratios of cationic and anionic species in explaining PM source and relationship between $\mathrm{NH}_{4}{ }^{+}, \mathrm{SO}_{4}{ }^{2-}$ and $\mathrm{NO}_{3}{ }^{-}$

Various equivalent concentration ratios were calculated for the water-soluble inorganic species, including the ion balance (expressed as the ratio of total cation equivalents to total anion equivalents), the ratios of individual cations to the total cations and of individual anions to the total anions, and the $\mathrm{Cl}^{-} / \mathrm{Na}^{+}$ratio. Figure 4 shows the relationship between the total cation equivalents against the total anion equivalents in PM10 data from the entire study period. The 
slope of the regression equation of the total cation data (in neq $/ \mathrm{m}^{3}$ ) on the total anion data $\left(n e q / \mathrm{m}^{3}\right)$ is 1.35 and the $\mathrm{r}^{2}$-value is 0.92 . This indicates that the total equivalent cation concentration was somewhat larger than that of the anions.

The median ratios and ranges for the fine and coarse size fractions for each of the three campaigns are given in Table 2. The median ion balance ratios are all larger than 1.0; they range from 1.30 to 1.44 for the fine size fraction and from 2.01 to 3.14 for the coarse size fraction. It should be indicated that carbonates were not measured by IC; these missing carbonates are thought to be largely responsible for the observed deviation from 1.0. If we assume that all the $\mathrm{Ca}^{2+}$ is present as $\mathrm{CaCO}_{3}$ and recalculate the ion balances with $\mathrm{Ca}^{2+}$ excluded, then the new median ion balance ratios range from 1.17 to 1.25 for the fine size fraction and from 1.02 to 1.22 for the coarse fraction. These new medians are all fairly close to 1.0 . That $\mathrm{Ca}^{2+}$ may be present as $\mathrm{CaCO}_{3}$ is not an unreasonable supposition, as limestone soils often contribute substantially to the mineral dust aerosol.

Table 2 further shows that $\mathrm{SO}_{4}{ }^{2-}$ is by far the most prominent anion and that $\mathrm{NH}_{4}{ }^{+}$is the main cation in the fine size fraction; in the coarse fraction, $\mathrm{Cl}^{-}$and $\mathrm{Ca}^{2+}$ are the main anionic and cationic species. As just indicated, $\mathrm{Ca}^{2+}$ may be present as $\mathrm{CaCO}_{3}$. With regard to $\mathrm{Cl}^{-}$, this may be mainly be derived from sea salt. To examine this, the $\mathrm{Cl} / \mathrm{Na}^{+}$equivalent ratios of Table 2 can be compared with the ratio of 1.18 for sea water (Brewer, 1975). The median $\mathrm{Cl}^{-} / \mathrm{Na}^{+}$ratios range from 0.18 to 0.26 for the fine size fraction and from 0.69 to 0.79 for the coarse size fraction. All these medians are substantially lower than the sea-water ratio. Not all $\mathrm{Na}^{+}$at the Morogoro site may originate from sea salt, though. There is also $\mathrm{Na}$ in mineral dust. Actually, the calculated crustal enrichment factor (EF) for coarse $\mathrm{Na}$ is near 1 , so that the low $\mathrm{Cl}^{-} / \mathrm{Na}^{+}$coarse medians may well be due to the contribution from mineral dust $\mathrm{Na}$. It should be noted here that at locations where there is virtually no contribution from sea salt, one often sees crustal EFs for $\mathrm{Na}$ of lower than 1 (sometimes even below 0.5), indicating that the EF of 1 does not imply that all the $\mathrm{Na}$ is fully derived from mineral dust. As to the fine size fraction, the mean crustal EFs for $\mathrm{Na}$ are about 2 in the two campaigns, suggesting that at least half of the fine $\mathrm{Na}$ may be coming from non-crustal sources, such as sea salt. Even taking this into account, we would never arrive at $\mathrm{Cl}^{-} / \mathrm{Na}^{+}$ ratios that approach that in sea water. It is well-known, though that $\mathrm{Cl}$ may be lost from the fine sea-salt aerosol because of reactions with acidic gases and acidic aerosol species (e.g., Graedel and Keene, 1995) both in the atmosphere and during the actual sampling.

The medians and ranges of the molar ratios of ammonium to sulphate and nitrate are also given in Table 2. As indicated above, in the fine size fraction, $\mathrm{SO}_{4}{ }^{2-}$ is by far the most prominent anion and $\mathrm{NH}_{4}{ }^{+}$is the main cation. In the neutralization of the precursor gases $\mathrm{H}_{2} \mathrm{SO}_{4}$ and $\mathrm{HNO}_{3}$ by $\mathrm{NH}_{3}$ gas and the formation of particulate compounds, $\mathrm{H}_{2} \mathrm{SO}_{4}$ is neutralized [first to $\mathrm{NH}_{4} \mathrm{HSO}_{4}$, then to $\left(\mathrm{NH}_{4}\right)_{2} \mathrm{SO}_{4}$ ] before the neutralization of $\mathrm{HNO}_{3}$ takes place. Only in the case of an ammoniarich environment will the $\mathrm{H}_{2} \mathrm{SO}_{4}$ and $\mathrm{HNO}_{3}$ be fully converted to the ammonium salts (Seinfeld and Pandis, 1998). It follows from the data in Table 2 that there was insufficient $\mathrm{NH}_{4}{ }^{+}$to fully neutralize $\mathrm{H}_{2} \mathrm{SO}_{4}$ to $\left(\mathrm{NH}_{4}\right)_{2} \mathrm{SO}_{4}$, in the fine size fraction, during the 2005 dry season campaign, but that there was nearly sufficient $\mathrm{NH}_{4}{ }^{+}$for this neutralization in the 2006 wet season campaign. $\mathrm{H}_{2} \mathrm{SO}_{4}$ and sulphate in the atmosphere are formed through homogeneous gas phase and heterogeneous gas/particle phase oxidation of $\mathrm{SO}_{2}$. The atmospheric lifetime of fine sulphate is in the order of several days (Seinfeld and Pandis, 1998), so it can be transported far away from the sources of the $\mathrm{SO}_{2}$. With regard to the sulphate in the coarse size fraction, this is to some extent primary (e.g., derived from sea salt) and in part secondary (formed from $\mathrm{SO}_{2}$ ). Table 2 indicates that a substantial fraction of the coarse sulphate may have been present as $\mathrm{NH}_{4} \mathrm{HSO}_{4}$ and $\left(\mathrm{NH}_{4}\right)_{2} \mathrm{SO}_{4}$ during the 2006 wet season campaign, but that there was very little of these ammonium salts in the 2005 dry season campaign. The neutralizing cations for coarse sulphate in this latter campaign must therefore have been alkali and/or earth alkali metals (e.g., $\mathrm{Ca}^{2+}$ ).

Fine particulate nitrate is formed by homogeneous gas phase oxidation of nitrogen oxides $\left(\mathrm{NO}_{\mathrm{x}}\right)$ to gaseous nitric acid, which is followed by the reaction with gaseous ammonia to form highly volatile $\mathrm{NH}_{4} \mathrm{NO}_{3}$. The distribution of $\mathrm{NH}_{4} \mathrm{NO}_{3}$ between the gas phase and particle phases depends mainly upon 
meteorological conditions (temperature and relative humidity), on the aerosol composition, and on the acidity of the particles. As indicated above, the chemical reaction between sulphuric acid and ammonia is the preferred chemical reaction in the atmosphere (Baek et al., 2004). As there was insufficient $\mathrm{NH}_{4}{ }^{+}$in the fine fraction to fully neutralize the fine sulphate, the formation of particulate $\mathrm{NH}_{4} \mathrm{NO}_{3}$ was inhibited and most of the $\mathrm{NO}_{3}{ }^{-}$may have been in the gas phase (as $\mathrm{HNO}_{3}$ ). However, gaseous nitric acid may react with alkaline particles, which are mainly present in the coarse size fraction, such as sea salt and soil particles (Pakkanen, 1996) and thereby be converted into coarse nitrate. It is therefore not surprising that more than half of the PM10 nitrate was present in the coarse size fraction (see Figure 3, especially 2006 wet season campaign), whereas PM10 ammonium and sulphate were predominantly associated with the fine aerosol.

\section{Influence of meteorology on the concentration of the PM mass and other aerosol components}

a) Impact of meteorology on the PM mass

Many studies have indicated that the PM10 mass concentrations in the ambient air are affected by various meteorological factors such as temperature, wind speed, rainfall, and relative humidity (Rajkumar and Chang, 2000). The daily average meteorological parameters (wind speed, cumulative precipitation, temperature, and relative humidity) were obtained from the Tanzania Meteorological Agency (SUA-station). The daily average wind speed during the campaigns ranged from 0.0 to $3.6 \mathrm{~m} / \mathrm{s}$. The winds were predominantly blowing from the south-east for most of the sampling periods. The daily average temperature ranged from 14 ${ }^{\circ} \mathrm{C}$ to $31{ }^{\circ} \mathrm{C}$. The daily mean relative humidity ranged from $50 \%$ to $90 \%$, with the lower value typically recorded in the dry season. The cumulative precipitation varied from nearly zero during the 2005 dry season campaign to $248 \mathrm{~mm}$ during the 2006 wet season campaign. The correlations of the PM10 mass concentrations with different meteorological parameters were examined.

Relationship between PM10 mass and total daily cumulative precipitation is shown in Figure 5(a). The PM10 mass concentration was systematically low during precipitation events.
It never exceeded $20 \mu \mathrm{g} / \mathrm{m}^{3}$ when the daily precipitation was higher than $5 \mathrm{~mm}$. The variation of PM10 mass concentration with daily mean temperature is shown in Figure 5(b). The concentrations were higher at low temperatures (below about $24{ }^{\circ} \mathrm{C}$ ) and high temperature (above about $27^{\circ} \mathrm{C}$ ), and reached a minimum for temperatures between 24 and $27{ }^{\circ} \mathrm{C}$. One could make a number of assumptions to explain this observation. The rise in concentration at low temperatures could be due to more frequent inversion events. The altitude of the site (526 m above sea level), as well as the morphology of the foothill of the Uluguru Mountain ranges, make that the site is rather sensitive to the phenomenon of temperature inversion. The higher PM10 mass concentrations at higher temperatures might be caused by more intense formation of secondary aerosols. The influence of the daily mean wind speed on PM10 mass (Figure 5(c)) is less clear than that of the meteorological parameters discussed above. Low wind speeds inhibit dilution whereas large wind speeds lead to increased soil dust mobilisation. It seems that the effects of decreased dilution and increased soil dust mobilisation were roughly of equal importance.

b) Impact of temperature and relative humidity on anion concentrations

The relationship between the atmospheric concentrations in PM10 of the anions and temperature and relative humidity was examined. To do this, the data were selected excluding rainy periods and classified according to ambient temperature and relative humidity levels. The sensitivity of particulate $\mathrm{SO}_{4}{ }^{2-}, \mathrm{NO}_{3}{ }^{-}$, and $\mathrm{Cl}^{-}$concentrations to changes of temperature and relative humidity is shown in Figure 6. There was virtually no dependence on relative humidity, while temperature dependence could be found. The change in particulate $\mathrm{SO}_{4}{ }^{2-}, \mathrm{NO}_{3}^{-}$, and $\mathrm{Cl}^{-}$concentrations with temperature resembles the change for the PM10 mass: lower levels at temperatures between 23 and $27^{\circ} \mathrm{C}$.

\section{Conclusion}

The concentrations of the watersoluble ions were influenced by the meteorology; higher mean concentration for the anions $\mathrm{Cl}^{-}, \mathrm{NO}_{3}^{-}$, and $\mathrm{SO}_{4}{ }^{2-}$ and the cations $\mathrm{Na}^{+}, \mathrm{NH}_{4}^{+}, \mathrm{K}^{+}, \mathrm{Mg}^{2+}, \mathrm{Ca}^{2+}$, were observed during the 2005 dry season campaign than during the 2006 wet season campaign. $\mathrm{NH}_{4}{ }^{+}$, $\mathrm{K}^{+}$, and $\mathrm{SO}_{4}{ }^{2-}$ were mainly present in the fine 
size fraction. The sea-salt elements $(\mathrm{Na}, \mathrm{Mg}$, $\mathrm{Cl}), \mathrm{Ca}^{2+}$, and $\mathrm{NO}_{3}^{-}$were predominantly associated with the coarse size fraction. However, $\mathrm{Ca}^{2+}$ was the most important cation and the $\mathrm{SO}_{4}{ }^{2-}$ main anionic species in PM10 while $\mathrm{NH}_{4}{ }^{+}$was the most abundant cation in References

Baek, B.H., V.P. Aneja, and Q. Tong, (2004), Chemical coupling between ammonia, acid gases, and fine particles. Environ.Poll., 129(1), 89-98

Bennet, C., P. Jonsson, and E. Selin Lindgren, (2005), Concentrations and sources of trace elements in particulate air pollution, Dar es Salaam, Tanzania, studied by EDXRF. X-Ray Spectrom., 34(1), 1-6.

Brewer, P.G., (1975), Minor elements in sea water. In: Chemical Oceanography, Vol. 1, Chester R. (Ed.), Academic Press, New York.

Dockery, D., and A. Pope, (1996), Epidemiology of acute health effects: Summary of time-series studies. In: Particles in Our Air: Concentration and Health Effects, Spengler, J. D. and Wilson, R. (Eds.), Cambridge, MA, Harvard University Press.

EU Directive 1999/30/EC, 1999. Council Directive relating to limit values for sulphur dioxide, nitrogen dioxide and oxides of nitrogen, particulate matter and lead in ambient air. The Council of the European Union.

Giri, D., V.K. Murthy, P.R. Adhikary, and S.N. Khanal, (2006), Ambient air quality of Kathmandu valley as reflected by atmospheric particulate matter concentrations (PM10). Int. J. Environ. Sci. Tech., 3(4), 403-410.

Graedel, T.E., and W.C. Keene, 1995. Tropospheric budget of reactive chlorine. Global Biogeochemical Cycles, 9(1), 47-77.

Harrison, R.M., A.M. Jones, and R.G. Lawrence, (2004), Major component composition of PM10 and PM2.5 from roadside and urban background sites, Atmos. Environ., 38(27), 4531-4538.

Hitzenberger, R., A. Berner, Z. Galambos, W. Maenhaut, J. Cafmeyer, J. Schwarz, K. Müller, G. Spindler, W. Wieprecht, K. Acker, R. Hillamo, and T. Mäkelä, (2004), Intercomparison of methods to measure the mass concentration of the atmospheric aerosol during INTERCOMP2000-influence of instrumentation and size cuts. Atmos. Environ., 38(38), 6467-6476.

Hopke, P.K., Y. Xie, T. Raunemaa, S. Biegalski, S. Landsberger, W. Maenhaut, P. Artaxo, D. Cohen, (1997), Characterisation of the fine size fraction and $\mathrm{Cl}^{-}$the main anionic species in the coarse fraction. The study suggest that primary sources such as soil dust dispersion and biomass burning made a significant contribution to the ambient particulate pollution in Morogoro atmosphere.

the Gent Stacked Filter Unit PM10 sampler. Aeros. Sci. Tech., 27,726-735.

Intergovernmental Panel on Climate Change (IPCC), (2007), IPCC fourth assessment report (2007), Cambridge University Press, London.

Koleleni, Y.I.A., (2002), Environmental air degradation in Dar es Salaam by X-ray fluorescence. J. Environ. Sci. and Health A, 37(3), 385-398.

Lee, H.S. and B.-W., Kang, (2001), Chemical characteristics of PM2.5 species in Chongju, South Korea, Atmos. Environ., 35(4),739-746.

Maenhaut, W., F. François, and J. Cafmeyer, (1994), The Gent stacked filter unit sampler for the collection of atmospheric aerosols in two size fractions: description and instructions for installation and use. In: Applied Research on Air Pollution Using Nuclear-related Analytical Techniques, IAEA Report NAHRES-19 Vienna.

Maenhaut, W., J. Schwarz, J. Cafmeyer, and X. Chi, (2002), Aerosol chemical mass closure during the EUROTRAC-2 AEROSOL Intercomparison 2000. Nucl. Instrum. Methods $B$ 189(1-4), 233-237.

McMurry, P.H. (2000), A review of atmospheric measurements. Atmos. Environ., 34(12-14), 1959-1999.

Mkoma, S. L., W. Maenhaut, X. Chi, W. Wang, and N. Raes, (2009a), Characterisation of PM10 Atmospheric Aerosols for the Wet Season 2005 at Two Sites in Tanzania, East Africa., Atmos. Environ., 43(3), 631-639.

Mkoma, S.L., W. Maenhaut, X. Chi, W. Wang, and N. Raes, (2009b), Chemical Composition and Mass Closure for PM10 Aerosols during the 2005 Dry Season at a Rural Site in Morogoro, Tanzania. X-Ray Spectrom., 38: 293-300.

Msafiri J. (2005), Roadside concentration of gaseous and particulate matter pollutants and risk assessment in Dar-es-Salaam, Tanzania. Environ Monit. and Assess., 104(1-3), 385407.

Nyanganyura, D., W.;Maenhaut, M. Mathuthu, A. Makarau, and F.X. Meixner, (2007), The chemical composition of tropospheric aerosols and their contributing sources to a continental 
background site in northern Zimbabwe from 1994 to 2000. Atmos. Environ., 41(12), 26442659.

Ocskay, R. I., Salma, W. Wang, and W. Maenhaut, (2006), Characterization and diurnal variation of size-resolved inorganic water-soluble ions at a rural background site. $J$. Environ. Monitor., 8(2), 300-306.

Pakkanen, T.A., (1996), Study of formation of coarse particle nitrate aerosol. Atmos. Environ., 30(14), 2475-2482.

Pope, C.A., R.T. Burnett, M.J. Thun, E.E. Calle, D. Krewski, K. Ito, G.D. Thurston, (2002), Lung cancer, cardio-pulmonary mortality and long-term exposure to fine particulate air pollution. J. American Medical Associ., 287(9): 1132-1141.

Putaud, J.-P., F. Raes, R. Van Dingenen, U. Baltensperger, E. Brüggemann, M.-C. Facchini, S. Decesari, S. Fuzzi, R. Gehrig, C. Hüglin, P. Laj, G. Lorbeer, W. Maenhaut, N. Mihalopoulos, K. Müller, X. Querol, S. Rodriguez, J. Schneider, G. Spindler, H. ten Brink, K. Tørseth, and A. Wiedensohler, 2004. A European aerosol phenomenology - 2: chemical characteristics of particulate matter at kerbside, urban, rural and background sites in Europe. Atmos. Environ., 38(16): 2579-2595.

Rajkumar, W.S. and A.S. Chang, 2000. Suspended particulate matter concentrations along the East-West Corridor, Trinidad, West Indies. Atmos. Environ., 34(8): 1181-1187.

Seinfeld, J.H. and S.N. Pandis, 1998. Atmospheric Chemistry and Physics: From Air Pollution to Climate Change, John Wiley and Sons, New York.

Tippayawong, N. P. Pengchai, and A. Lee, 2006. Characterization of ambient aerosols in
Northern Thailand and their probable sources. Int. J. Environ. Sci. Tech., 3(4): 359-369.

Turnbull, A.B. and R.M. Harrison, 2000. Major component contributions to PM10 in the UK atmosphere, Atmos. Environ., 34(19): 3129-3137.

Van Dingenen, R., F. Raes, J.-P. Putaud, U. Baltensperger, A. Charron, M.-C. Facchini, S. Decesari, S. Fuzzi, R. Gehrig, H.-C. Hansson, R.M. Harrison, C. Hüglin, A.M. Jones, P. Laj, G. Lorbeer, W. Maenhaut, F. Palmgren, X. Querol, S. Rodriguez, J. Schneider, H. ten Brink, P. Tunved, K. Tørseth, B. Wehner, E. Weingartner, A;Wiedensohler, and P. Wåhlin, 2004. A European aerosol phenomenology - 1: physical characteristics of particulate matter at kerbside, urban, rural and background sites in Europe. Atmos. Environ., 38(16): 2561-2577. Villeneuve, P.J., R.T. Burnett, Y. Shi, D. Krewski, M.S. Goldberg, C. Hertzman, Y. Chen, and J. Brook, 2003. A time-series study of air pollution, socioeconomic status, and mortality in Vancouver, Canada. J Exposure Analy. Environ. Epidemiol., 13(6): 427-435.

Watson, J.G., 2002. Visibility: science and regulation. J. Air and Waste Managt. Associ., 52 (6), 628-713.

Wilson, W.E., J.C. Chow, C. Claiborn, F.S. Wei, J. Engelbrecht, and J.G. Watson, 2002. Monitoring of particulate matter outdoors. Chemos. 49(9): 1009-1043.

\section{Acknowledgments}

This research was funded by the Flemish Interuniversity Council (SUA-VLIR program) and the Belgian Federal Science Policy Office. The authors wish to thank Sheila Dunphy and Jan Cafmeyer for their assistance and the logistics 
Table 1. The mean mass concentration and associated standard deviation (in neq $/ \mathrm{m}^{3}$ ) of water-soluble.

\begin{tabular}{|c|c|c|c|c|c|c|c|c|}
\hline & \multicolumn{4}{|c|}{2005 dry season } & \multicolumn{4}{|c|}{2006 wet season } \\
\hline & \multicolumn{2}{|c|}{ Fine } & \multicolumn{2}{|l|}{ Coarse } & \multicolumn{2}{|l|}{ Fine } & \multicolumn{2}{|l|}{ Coarse } \\
\hline & Mean & Std.dev. & Mean & Std.dev. & Mean & Std.dev. & Mean & Std.dev. \\
\hline $\mathrm{NH}_{4}^{+}$ & 371.33 & 339.80 & 12.04 & 24.67 & 154.09 & 88.98 & 9.76 & 7.99 \\
\hline $\mathrm{SO}_{4}{ }^{2-}$ & 1881.69 & 1037.99 & 419.38 & 196.08 & 452.64 & 258.84 & 96.71 & 84.59 \\
\hline $\mathrm{NO}_{3}^{-}$ & 774.79 & 480.70 & 823.07 & 416.44 & 63.82 & 27.30 & 167.22 & 172.35 \\
\hline $\mathrm{Cl}^{-}$ & 168.74 & 123.96 & 909.69 & 364.88 & 10.76 & 8.38 & 138.98 & 165.82 \\
\hline $\mathrm{Na}^{+}$ & 306.98 & 110.82 & 750.54 & 254.10 & 36.30 & 23.11 & 120.67 & 131.09 \\
\hline $\mathrm{Mg}^{2+}$ & 20.79 & 8.98 & 140.40 & 38.49 & 5.46 & 3.42 & 28.05 & 15.94 \\
\hline $\mathrm{K}^{+}$ & 1221.27 & 557.80 & 146.79 & 46.30 & 71.95 & 26.94 & 55.33 & 12.80 \\
\hline $\mathrm{Ca}^{2+}$ & 117.31 & 44.19 & 961.86 & 346.71 & 35.39 & 21.35 & 313.98 & 194.49 \\
\hline
\end{tabular}

Table 2. Medians (and ranges) of concentrations in the fine and coarse size fractions at Morogoro.

\begin{tabular}{|c|c|c|c|c|}
\hline \multirow[t]{2}{*}{ Species } & \multicolumn{2}{|c|}{ Fine size fraction } & \multicolumn{2}{|c|}{ Coarse size fraction } \\
\hline & Median & Range & Median & Range \\
\hline \multicolumn{5}{|l|}{2005 dry } \\
\hline cations/anions & 1.30 & $(1.12-1.64)$ & 2.01 & $(1.21-5.45)$ \\
\hline $\mathrm{NH}_{4}{ }^{+} /$cations & 0.22 & $(0.07-0.71)$ & 0.002 & $(0.00-0.06)$ \\
\hline $\mathrm{Na}^{+} /$cations & 0.21 & $(0.07-0.36)$ & 0.36 & $(0.09-0.55)$ \\
\hline $\mathrm{Mg}^{2+} /$ cations & 0.02 & $(0.005-0.067)$ & 0.12 & $(0.07-0.16)$ \\
\hline $\mathrm{K}^{+} /$cations & 0.45 & $0.17-0.62)$ & 0.04 & $(0.02-0.08)$ \\
\hline $\mathrm{Ca}^{2+} /$ cations & 0.08 & $(0.02-0.23)$ & 0.48 & $(0.24-0.81)$ \\
\hline $\mathrm{NO}_{3}{ }^{-}$/anions & 0.23 & $(0.05-0.43)$ & 0.27 & $(0.01-0.44)$ \\
\hline $\mathrm{SO}_{4}{ }^{2-} /$ anions & 0.69 & $(0.39-0.93)$ & 0.16 & $(0.11-0.32)$ \\
\hline $\mathrm{Cl}^{-}$/anions & 0.08 & $(0.01-0.26)$ & 0.54 & $(0.24-0.82)$ \\
\hline $\mathrm{Cl}^{-} / \mathrm{Na}^{+}$ & 0.26 & $(0.07-1.21)$ & 0.79 & $(0.39-1.09)$ \\
\hline $\mathrm{NH}_{4}{ }^{+} / \mathrm{SO}_{4}{ }^{2-}$ & 0.92 & $0.45-1.97$ & 0.09 & $0.0-1.71$ \\
\hline $\mathrm{NH}_{4}^{+} /\left(2 \mathrm{SO}_{4}^{2-}\right)$ & 0.46 & $0.22-0.99$ & 0.04 & $0.0-0.17$ \\
\hline $\mathrm{NH}_{4}^{+} /\left(2 \mathrm{SO}_{4}^{2-}+\mathrm{NO}_{3}^{-}\right)$ & 0.34 & $0.12-0.93$ & 0.01 & $0.0-0.21$ \\
\hline \multicolumn{5}{|l|}{2006 wet } \\
\hline cations/anions & 1.34 & $(1.05-1.59)$ & 3.14 & $(1.28-8.09)$ \\
\hline $\mathrm{NH}_{4}{ }^{+} /$cations & 0.59 & $(0.37-0.79)$ & 0.02 & $(0.01-0.12)$ \\
\hline $\mathrm{Na}^{+} /$cations & 0.11 & $(0.03-0.19)$ & 0.17 & $(0.02-0.48)$ \\
\hline $\mathrm{Mg}^{2+} /$ cations & 0.03 & $(0.01-0.05)$ & 0.09 & $(0.06-0.13)$ \\
\hline $\mathrm{K}^{+} /$cations & 0.13 & $(0.06-0.36)$ & 0.06 & $(0.02-0.16)$ \\
\hline $\mathrm{Ca}^{2+} /$ cations & 0.12 & $(0.04-0.32)$ & 0.63 & $(0.38-0.82)$ \\
\hline $\mathrm{NO}_{3}{ }^{-}$/anions & 0.09 & $(0.06-0.21)$ & 0.29 & $(0.14-0.40)$ \\
\hline $\mathrm{SO}_{4}{ }^{2-}$ /anions & 0.86 & $(0.69-0.94)$ & 0.22 & $(0.09-0.58)$ \\
\hline $\mathrm{Cl}^{-}$/anions & 0.03 & $(0.00-0.09)$ & 0.43 & $(0.12-0.56)$ \\
\hline $\mathrm{Cl}^{-} / \mathrm{Na}^{+}$ & 0.19 & $(0.00-0.79)$ & 0.70 & $(0.45-2.91)$ \\
\hline $\mathrm{NH}_{4}{ }^{+} / \mathrm{SO}_{4}{ }^{2-}$ & 1.84 & $1.37-2.58$ & 0.79 & $0.31-4.32$ \\
\hline $\mathrm{NH}_{4}^{+} /\left(2 \mathrm{SO}_{4}{ }^{2-}\right)$ & 0.91 & $0.68-1.29$ & 0.40 & $0.16-2.16$ \\
\hline $\mathrm{NH}_{4}^{+} /\left(2 \mathrm{SO}_{4}{ }^{2-}+\mathrm{NO}_{3}^{-}\right)$ & 0.84 & $0.61-1.08$ & 0.14 & $0.04-0.88$ \\
\hline
\end{tabular}




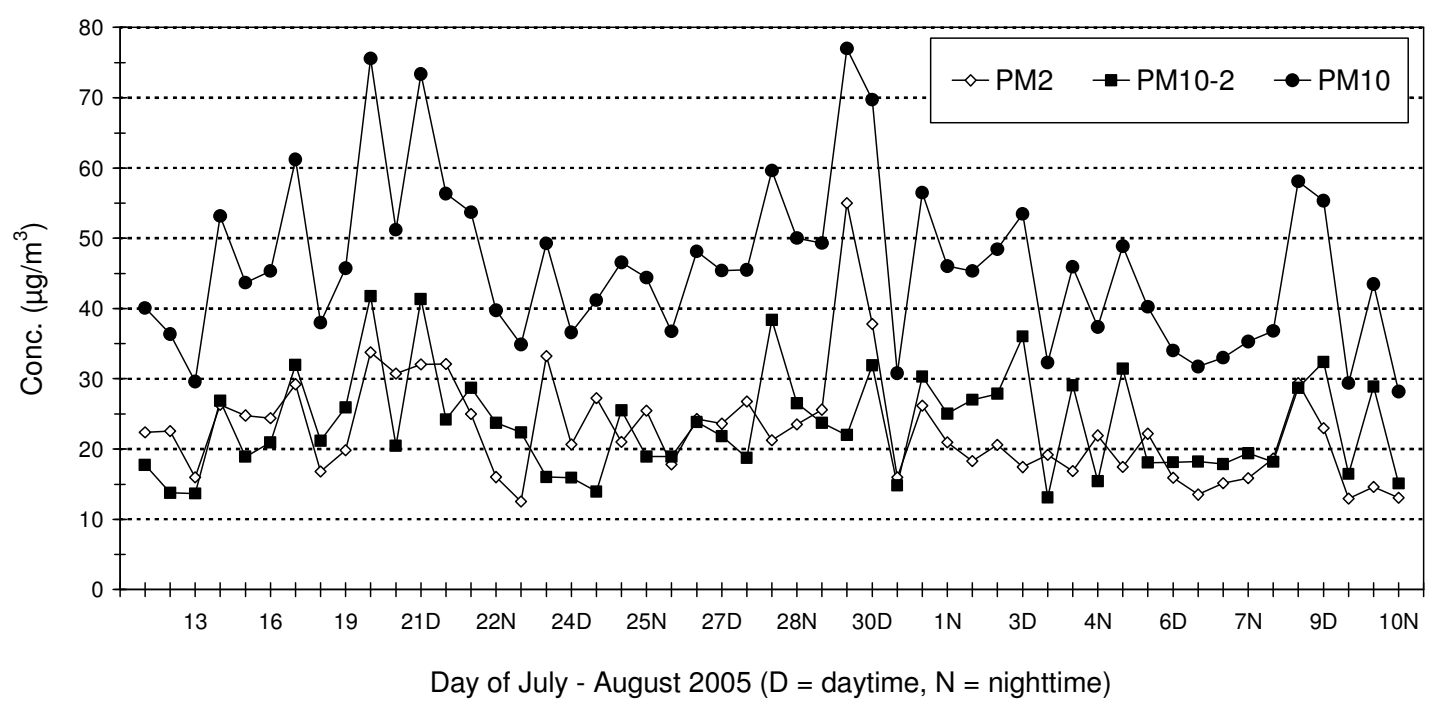

Figure 1. Time series of the PM mass in the fine, coarse and PM10 size fractions at Morogoro during the 2005 dry season campaign.

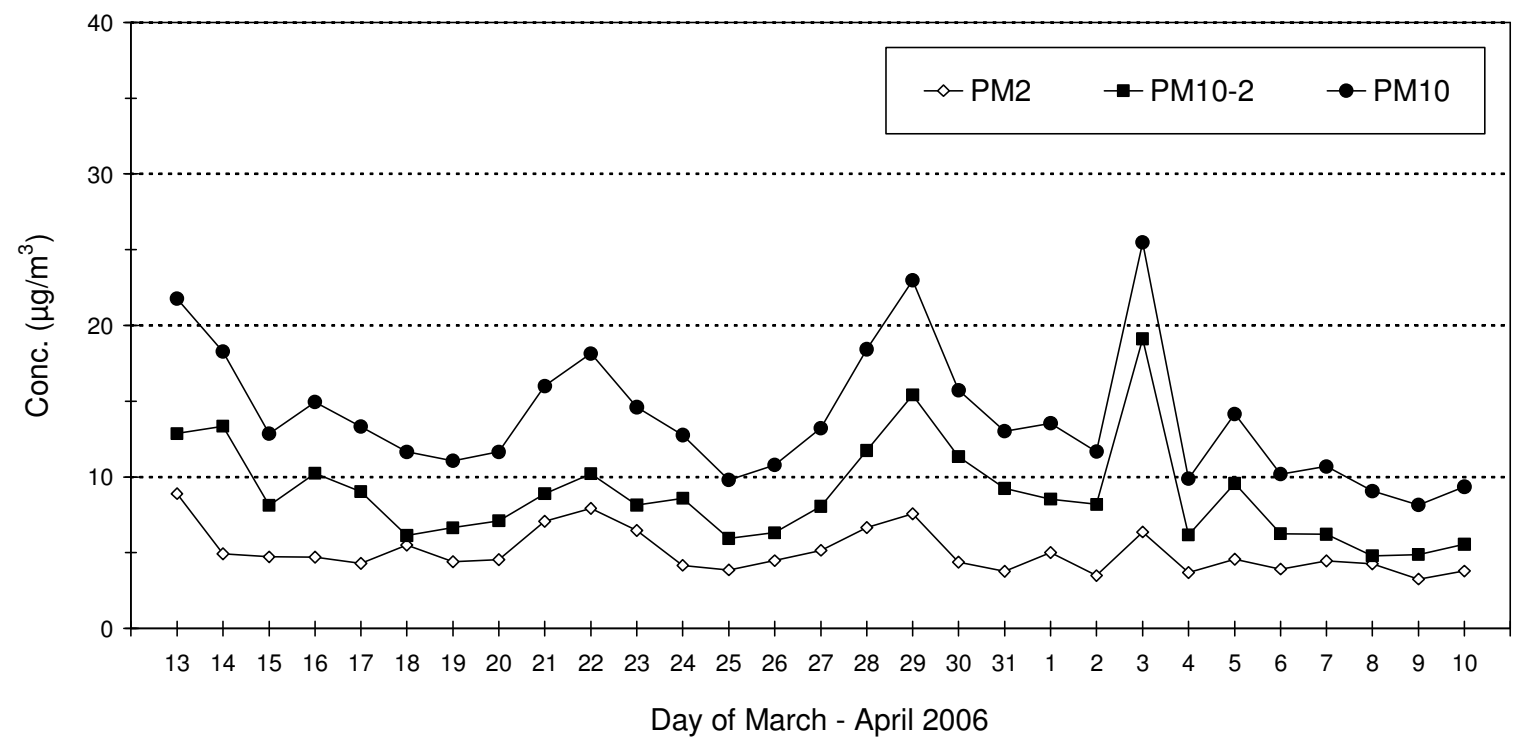

Figure 2. Time series of the PM mass in the fine, coarse and PM10 size fractions at Morogoro during the 2006 wet season campaign. 


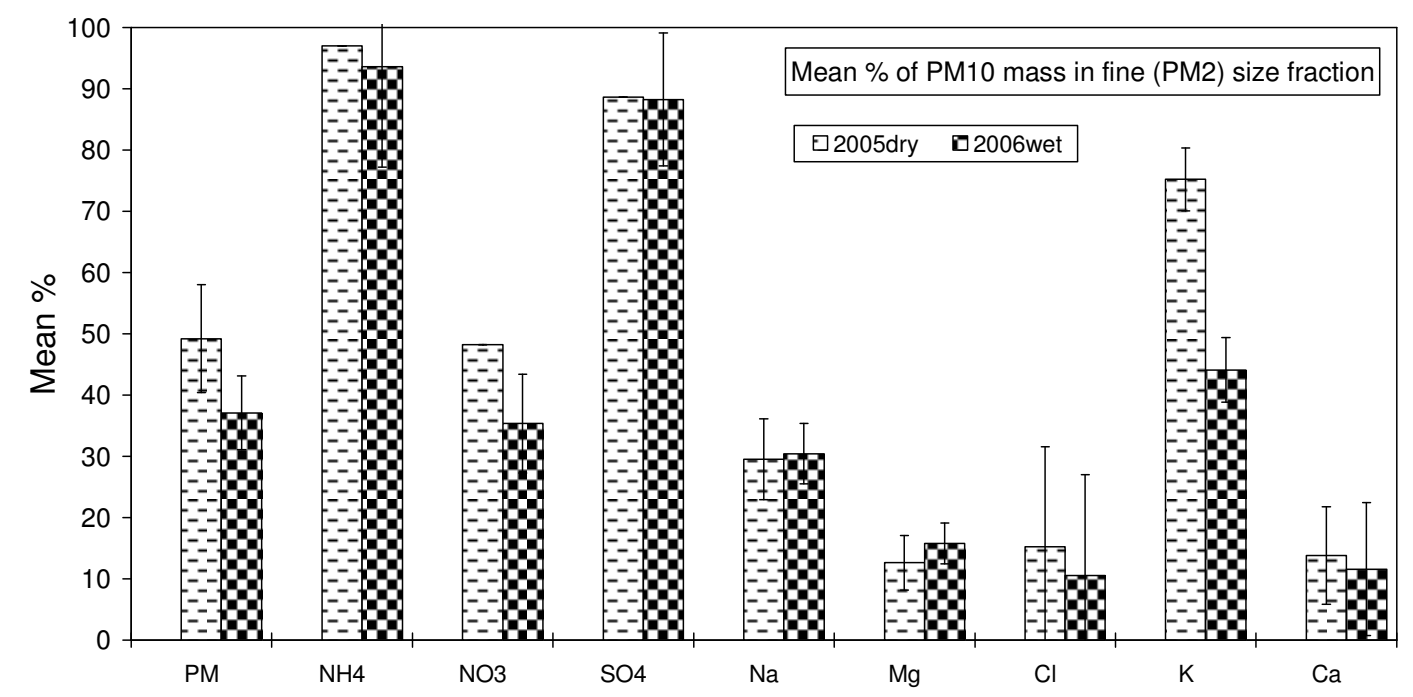

Figure 3. Mean percentage and associated standard deviation of the PM10 aerosol in the fine (PM2) size fraction for the PM mass and the water soluble inorganic ions during 2005 dry season and 2006 wet season campaigns in Morogoro.

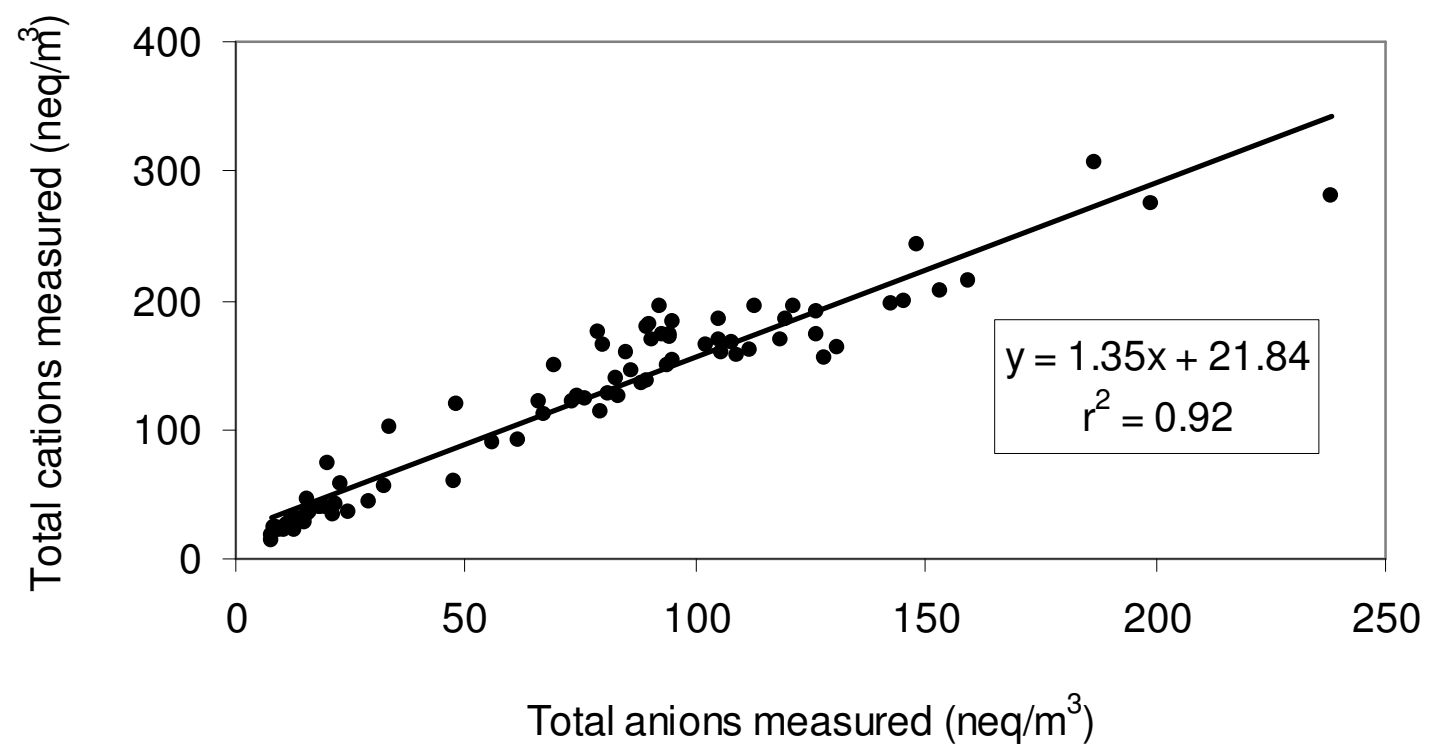

Figure 4. The correlation between total cations and anions measured in PM10 $(N=80)$ for Morogoro during the study period. 


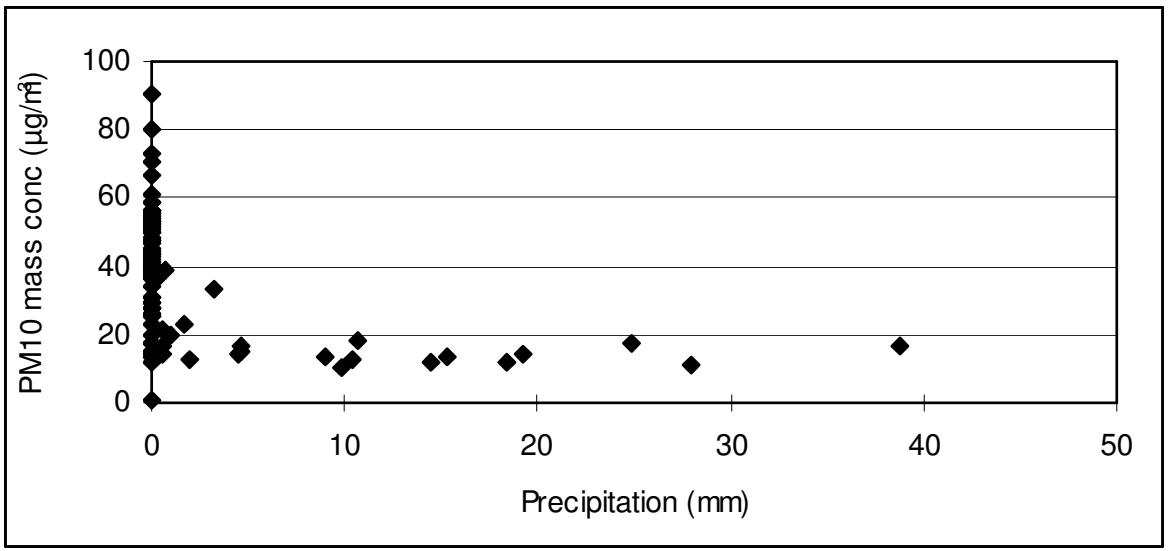

Figure 5a. Relationship between PM10 mass and total daily cumulative precipitation,

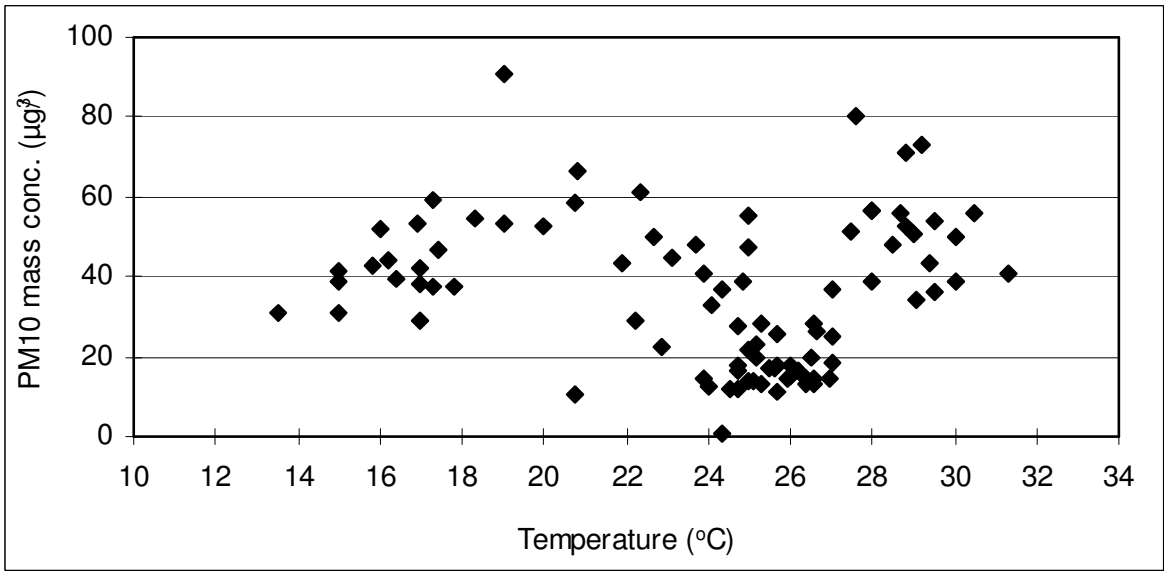

Figure 5b. Relationship between PM10 mass and daily mean temperature

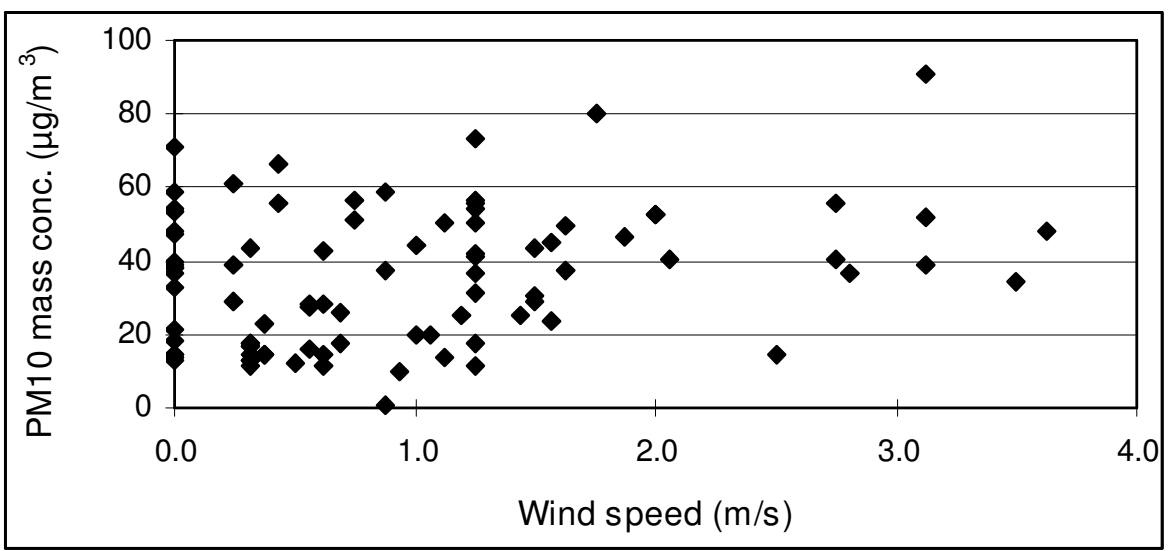

Figure 5c. Relationship between PM10 mass and daily mean wind speed. 


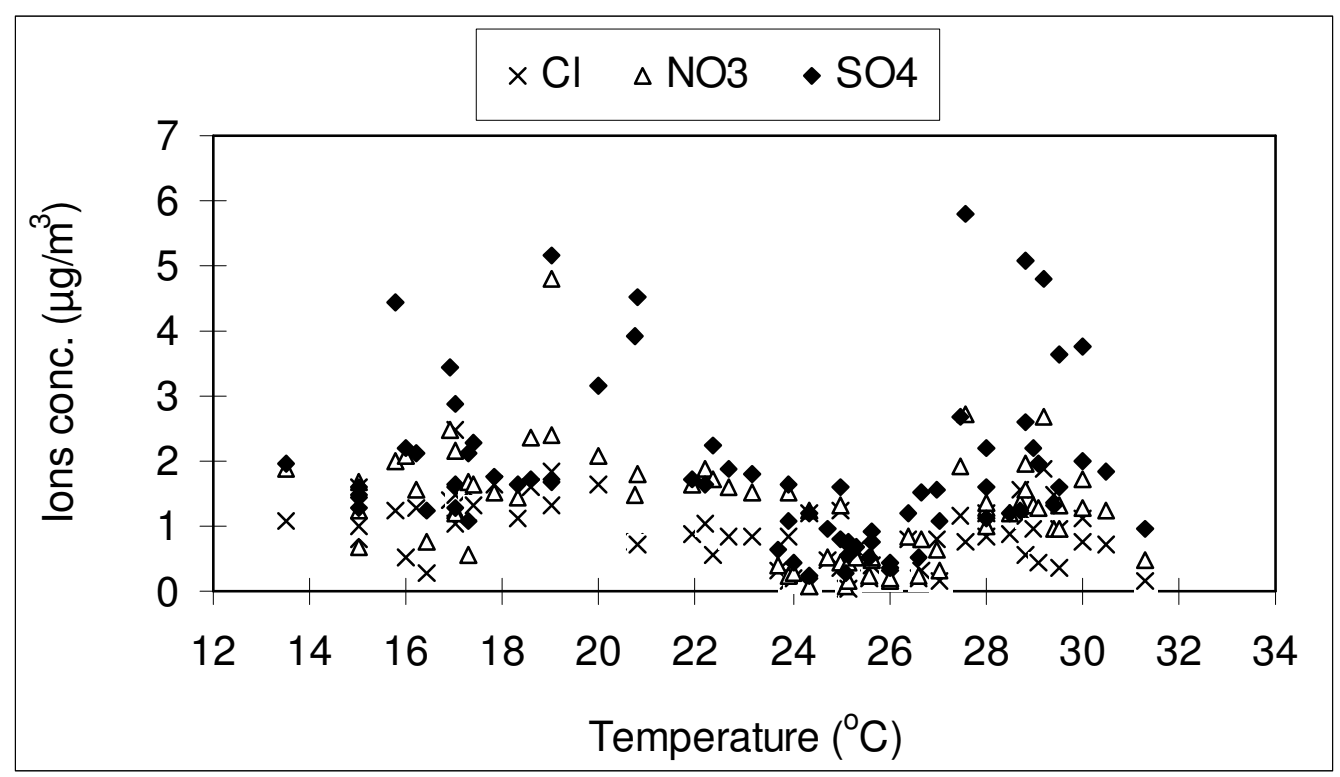

Figure 6a. Relationship between the atmospheric concentration of the anions and temperature

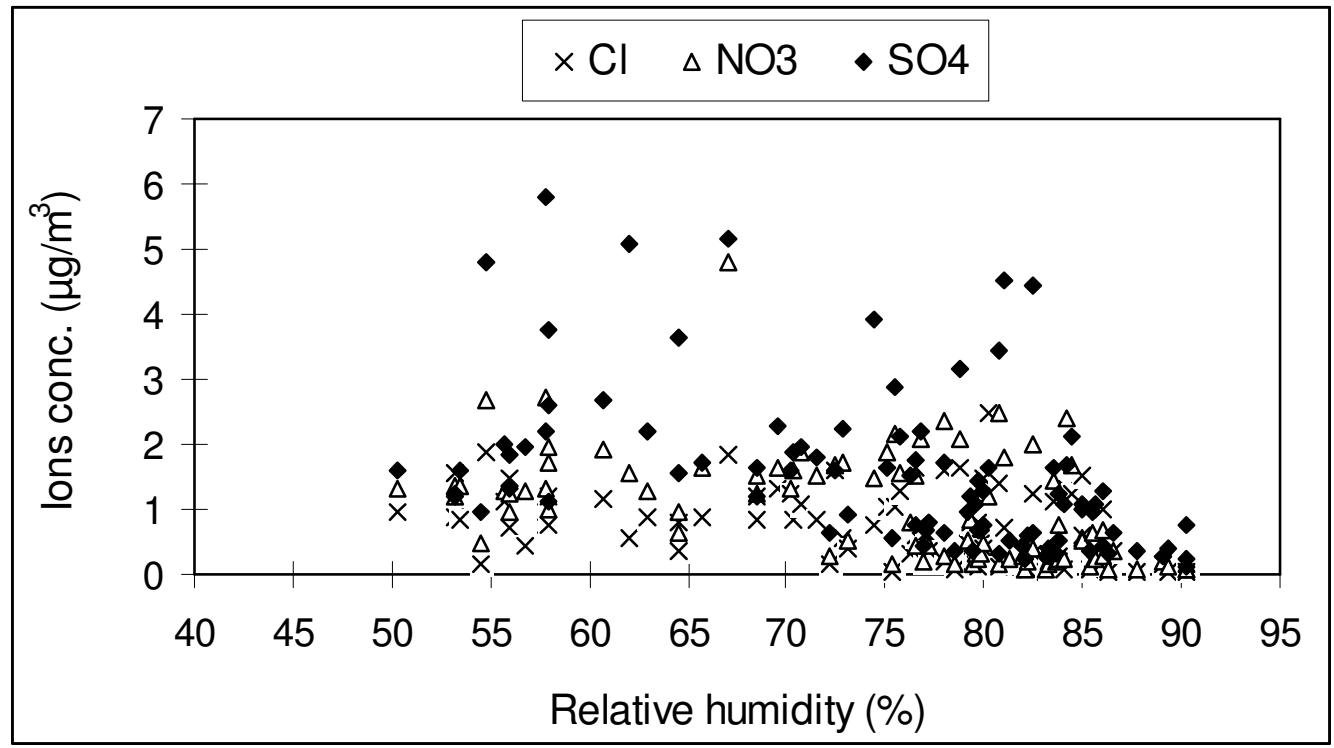

Figure 6b. Relationship between the atmospheric concentration of the anions and relative humidity. 